\title{
SWAZILAND \\ DIE GEOLOGIE EN GEOGRAFIE VAN SWAZILAND
}

DEEL I.

\author{
DIE GEOLOGIE VAN SWAZILAND
}

A. ALGEMENE GEOLOGIE

\section{Algemeen:}

In 1943 het die eerste werklike grootskaalse kartering van die gebied 'n aanvang geneem. En van 1949 af, met die koms van die eerste stel lugfoto's, is hierdie tempo versnel. Die basiese opname van die gebied is dan ook in 1957 voltooi.

In die eerste stadiums van kartering is die klassifikasie van die verskillende rotstopes gevolg soos wat dit deur Hall en later Van Eeden gedoen is. Soos die werk gevorder het, is veranderings ingevoer om die klassifikasie aan te pas by plaaslike omstandighede, maar nie almal hiervan het die toets van die tyd deurstaan nie.

As gevolg van kartering in die Forbes Reef-gebied is dit aanvaar dat daar twee kenmerkende onderdamme van ultrabasiese, instrusiewe rotse is, naamlik 'n ouer Jamestownkompleks, hoofsaaklik veranderde talk sjiste en 'n jonger Havelockkompleks wat nie alleen uit serpenteniete bestaan nie, maar ook uit dioriete en gabbros. Die geldigheid van 'n Havelockkompleks kan nie bewys word nie. Daar is gevind dat die serpenteniete inderdaad van Jamestown-ouderdom was, maar dat die dioriete en gabbros jonger is as die graniete wat ingedring het in die Jamestownkompleks en Swazilandsisteem. Hurter (1950) het voorgestel dat dit die Usushwanakompleks genoem moet word. Die term hou eerder 'n geografiese as 'n geologiese betekenis in.

In die Republiek word dit aanvaar dat die diskonformiteit aan die basis van die Moodiesserie van genoegsame betekenis is om die genoemde serie van die onderliggende Figtree- en Onverwachtseries te skei. In Swaziland kon Urie (1956) en Leutz (1954) nie genoegsame bewys vir so 'n verdeling vind 
nie en daarom word die Swazilandsisteem nog steeds gedefinieer om ook die Moodiesserie in te sluit.

Die status van die Pongolasisteem was onderhewig aan aansienlike debat. Die Geologiese opname van S.A. stel twee afdelings vir die sisteem voor (naamlik die Insuzi- en Mozaanseries), wat gekorreleer kan word met die Dominium Reefen Witwatersrandsisteem respektiewelik. Die offisiële mening in Swaziland is nog steeds ' $n$ debatspunt.

Een van die hoof-oogmerke van die opname in Swaziland was om daardie gebiede wat die waarskynlikste gemineraliseer kan wees, af te baken en omdat byna $\frac{3}{3}$ van Swaziland onderlê word deur graniet, was dit essensieel om die granietterrein in meer hanteerbare eenhede op te deel. Die graniete is dus in vyf hoofeenhede ingedeel waarvan twee beskou is as preInsuzi- en die res as na-Insuzi- of na-Mozaan-ouderdom te wees. Later is die klassifikasie of geamendeer sover dit die eerste drie eenhede betref. G1 is nou gereserveer vir graniete en gneise wat uitgesluit is by die genommerde eenhede. Die G2 graniet word beskou as 'n fase van G4 en G3 as van naSwaziland-ouderdom en nie definitief na-Insuzi soos wat oorspronklik gemeen is nie.

\section{Huidige Stratigrafie:}

Die argaïse rotse in Swaziland is van die oudste bekendes in die wêreld en dateer sowat 3,000 miljoen jaar terug. Basiese en suur vulkanisme van die Onverwachtseries is in ' $n$ onstabiele kom uitgepers en is gevolg deur 'n opeenvelging van pelitiese sedisnente met ondergeskikte lawas (die Figtree-serie). 'n Periode van plooiing word gevolg deur 'n afsetting van growwer sedimente, nou verteenwoordig deur die Moodeisserie. Intrusief in al hierdie voorafgaande rotstipes is die basiese en ultrabasiese gesteentes van die Jamestownkompleks. $\mathrm{Na}$ die indringing van die Jamestown was die gebied onderhewig aan intensiewe deformasie wat ooreenkom met groot soortgelyke gebiede in die Republiek. In die diepte is die sedimente, vulkaniese rotse en indringings getransformeer in gneisse met tipiese samestelling, terwyl granietmagma gevorm is. Soos wat die paradoks van die orogenie minder aktief geword het, het magma ingedring in die boonste korsdele om daar te konsoli- 
deer soos wat ons dit vandag sien. Behalwe vir die metamorfiese veranderinge in die diepte is rotse in die boonste lae geplooi, gebreek en geskeur. Uiteindelik het spanningskrake ontstaan waar langs gange van diabaas gevolglik ingedring het.

Gedurende 'n periode van relatiewe stabiliteit, wat gevolg het, is die groot bergkettings gelyk geërodeer. Geen rekord van hierdie lang periode het oorgebly nie, totdat koue toestande die begin van die Karroosisteem-tydperk voorafgegaan het. Hierdie tydperk ondervind ' $n$ geleidelike toename in temperatuur en gevolglik ook 'n weelderige plantegroei. Semiwoestyntoestande heers na die einde van hierdie periode waarin talle spesies van reptiele algemeen voorgekom het. Die Karroo-tydperk word afgesluit deur 'n tydperk van vulkaniese aktiwiteit. Die sedisnente en vulkasniese rotse van die Karroo is effens na die ooste gekantel en het meestal behoue gebly in die bosveldstreke van Swaziland. Weer eens het Swaziland deur ' $n$ ander periode van erosie en skiervlaktevorming gegaan wat vandag nog aan die gang is.

\section{B. DIE MINERALE HULPBRONNE VAN SWAZILAND}

\section{Die geskiedenis van die mynindustrie:}

Alhoewel dit bekend is uit vroeë werkplekke dat yster gedelf is in Swaziland voor die koms van die Swazi's, het die eerste mynbedrywigheid eers plaasgevind na die koms van die blankes in die tweede helfte van die 19e eeu. Die ontdekking van goud in die Forbes Reef-gebied gedurende die laat sewentiger jare het gelei tot die toekenning van die eerste mineraalkonsessie deur die toendertydse Swazikoning, Mbandzeni op 10 Maart 1882.

Die produksie van goud het in 1882 ' $n$ aanvang geneem en was vir jare die vernaamste mineraal tot in 1913 toe daar, waarskynlik weens die eerste wêreldoorlog, 'n afname in die goudproduksie was. In die tussentyd is tin, in die vorm van cassiteriet in 1883 in Swaziland ontdek en het slegs met enkele geleenthede goud verbygesteek voor 1913 wat produksie aanbetref. $\mathrm{Na}$ hierdie datum het dit egter 'n belangrike rol in die mynindustrie van Swaziland gespeel tot die aanvang van asbesproduksie by die Havelockmyn in 1939 begin het. Van daardie tydstip af het tinproduksie begin afneem en ten 
spyte van 'n nuwe groeiende goudmynbedryf het asbes sedertdien die vernaamste rol in die mynindustrie gespeel.

Die onderstaande tabel toon die totale waarde van al die minerale wat geproduseer is van 1907 af, die jaar van die vroegste beskikbare rekords tot op 31 Desember 1961.

TABEL 1.

Chrisotiel-asbes

$\mathrm{R} 68,689,177$

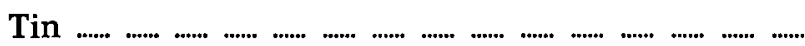

Goud .....................................................................................

$3,617,034$

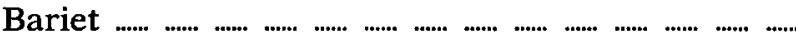

$1,392,934$

Steenkool ..............................................................................

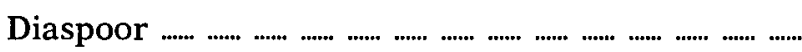

Pirophylliet .............................................................................

Yttrotantaliet ........................................................................

Korundum ..................................................................................

84,105

48,990

31,009

24,146

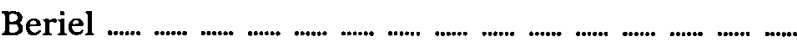

Silwer ...................................................................................

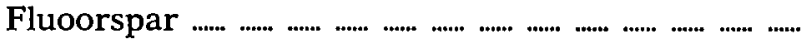

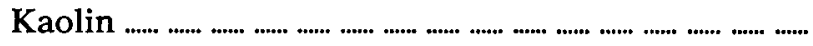

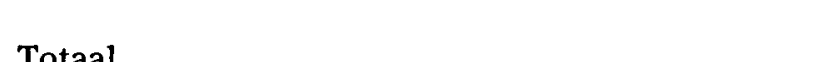

$\mathrm{R} 73,902,362$

Vir vergelykende doeleindes word die volgende tabel ook ingesluit en dui die minerale produksie van die jare 1960 en 1961 aan:

TABEL 2.

1960

1961

Chrisotiel Asbes ........................

Tin .................................................

Steenkool ................................................

Bariet ..................................................

Diaspoor …......................................

Pirophylliet ....................................

Beriel ..............................................

$\mathrm{R} 5,572,958$

9,982

39,130

3,450

8,312

5,200

1,420

R5,070,321

9,864

3,272

7,041

Kaolien ............................................

Goud ............................................

Silwer ….....................................

20,280

5,137

13,904

1,652

439

Totaal ….................................. 
TABEL 3.

(Dui die mineraal-uitvoere in 1961 aan).

\begin{tabular}{|c|c|c|}
\hline Mineraal & Land waarheen uitgevoer & Waarde \\
\hline \multirow[t]{9}{*}{ Chrysotiel-asbes: } & Australië & \\
\hline & 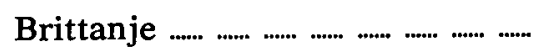 & $\mathrm{R} 3,634,769$ \\
\hline & Denemarke $\ldots \ldots \ldots \ldots$ & 408 \\
\hline & Finland $\ldots \ldots$ & 780 \\
\hline & Frankryk & 43,316 \\
\hline & 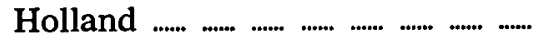 & 2,042 \\
\hline & Meksiko & 17,160 \\
\hline & Rep. van S.A. & 982,047 \\
\hline & Spanje & 389,799 \\
\hline Diaspoor: & Rep. van S.A. & 9,864 \\
\hline Bariet: & Rep. van S.A. .................................. & 7,041 \\
\hline \multirow[t]{2}{*}{ Tin-konsentraat: } & Wes-Duitsland $\ldots \ldots \ldots \ldots \ldots$ & 1,920 \\
\hline & Japan $\ldots . . . . . . . . . . . . . .$. & 3,217 \\
\hline Pirofilliet: & Rep. van S.A. $\ldots \ldots \ldots \ldots \ldots$ & 13,904 \\
\hline Beriel: & 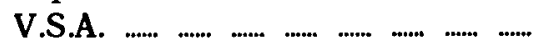 & 1,652 \\
\hline Kaolien: & 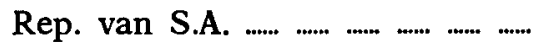 & 439 \\
\hline Goud: & 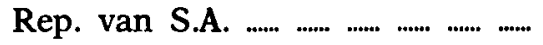 & 33,130 \\
\hline Silwer: & Rep. van S.A. $\ldots \ldots \ldots \ldots$ & 66 \\
\hline
\end{tabular}

Die eienaarskap van minerale regte is heeltemal geskei van oppervlak-eienaarskap en is verdeel tussen privaat persone of maatskappye en die Staat.

In die geval van publieke of privaat mynmaatskappye is die belastingheffing $25 \mathrm{c}$ vir elke $\mathbf{R} 1$ met 'n belasbare inkome tot op $R 20,000$ en daarna 34 c vir elke R1 oor R20,000.

\section{Die edelmetale.}

Goud:

Die datum van die eerste goudontdekkings in Swaziland is nie bekend nie, maar dit is nie onredelik om te aanvaar dat die eerste prospekteerders hulle weg in Swaziland gevind het 
ten tye van die goud-stormloop in die Babertonse distrik in die latere helfte van 1870 nie. Geen data is beskikbaar oor hierdie periode nie, alhoewel daar honderde prospekteergate, skagte en slote in die Oshoek- en Horogebiede bestaan wat getuig van aansienlike aktiwiteit van hierdie vroeë prospekteerders.

Die goudmyne en prospekteerplekke is almal gekonsentreer in die rotse van die Swazilandsisteem in 'n gordel langs die noordwestelike grens van Oshoek tot by Horo. Dis is ' $n$ gebied van komplekse geologie met uitgebreide plooiing, oorplooiing en skeuring. Die goudmyne kom voor veral in twee gebiede, naamlik:

(a) In die Forbes Reef-gebied, en

(b) In die Pigg's Peak-distrik.

(a) Die Forbes Reef-gebied.

Die goudmyne in hierdie gebied lê in 'n min of meer perdeskoenvorm naby aan die Jamestown Kompleks-Moodie Seriekontak.

Die meerderheid van hierdie ontdekkings het nie verder as die prospekteerstadium ontwikkel nie. Nege myne is ontwikkel waarvan Forbes Reef die grootste was. Al hierdie myne was rustend sedert 1913 en dit was eers in 1960 dat daar weer 'n oplewing gekom het met die ontwikkeling van die She-myn.

(b) Die Pigg's Peak-distrik.

Die myne van hierdie distrik is in fyner besonderhede ondersoek as die van die vorige gebied. Die Pigg's Peak-myn is verreweg die grootste produseerder gevolg deur die Daisy. en Kobolondomyne.

Die myne is geleë in 'n hoogs gedisekteerde omgewing wat onderlê word deur sedimente van die Figtree-serie en ingedring deur ultrabasiese rotse van die Jamestownkompleks.

\section{Platinum metale:}

Platinum metale is nog nie in ekonomiese hoeveelhede in Swaziland ontdek nie alhoewel spore daarvan reeds gevind is naby Mankaiana.

Silwer:

Silwer word in Swaziland geproduseer as 'n byproduk van 
goud, aangesien daar geen ekonomiese silwervoorkomste is nie.

3. Basiese metaalminerale.

\section{Antimoon:}

Reeds in 1903 was dit al bekend dat Antimoon in die Forbes Reefgebied voorkom in 'n rif wat byna suiwer metalies is en 'n waarde van 25 dwts. per ton opgelewer het. Ten spyte van alle pogings om hierdie rif te herontdek bly sy posisie nog onbekend. Die antimoon wat nou ontgin word, kom in die gebied van die She-myn voor.

Beriel is sover die enigste berillium-draende mineraal wat in Swaziland gevind word en die voorkoms is beperk tot die granietpegmatiete en dan veral in die gebied van die Sincenberge.

Daar is geen myne of steengroewe waar beriel in die pegmatiete gedelf word nie, maar die voorkomste word deur die Swazi's ontgin as 'n sg. huisnywerheid (,village industry").

\section{Koper:}

Verslae oor die voorkoms van koper is algemeen in Swaziland. Daar is heeluat malagiet en kopersulfides aanwesig, maar op die oomblik word dit nog nie ekonomies ontgin nie.

\section{Yster:}

Die beste voorkoms van ysterafsettings in Swaziland is die van die Bomvu Ridge-gebied in 'n bergagtige streek sowat 16 myl ten noordooste van Mbabane en 2 myl van die Transvaalse grens. In 1961 is aangekondig dat 'n spoorweg van Ngwenya (Bomvu Ridge) na Goba gebou gaan word en die primêre funksie van die spoorweg is om die ystererts te vervoer. Die Anglo American Corporation het met die ontwikkeling van hierdie erts begin aangesien hulle 'n kontrak met Japannese kopers aangegaan het om hulle te voorsien van 12 miljoen ton erts oor 'n tydperk van 10 jaar. Mynbedrywighede het in 1963 'n aanvang geneem en die eerste verskepings moet gedurende die loop van hierdie jaar plaasgevind het. 
Tin:

Tin is die eerste ontgin in die Mbabanarivier by Mbabana in 1892. Die produksie het in die afgelope jare geweldig afgeneem namate die afsettings uitgeput geraak het.

4. Nie-metaliese minerale.

Diaspoor:

Dit kom in die gebied om Sicunusa voor en is in 1949 ontdek. Hoeveelhede tot 'n bedrag van R3,190 is tot in 1961 uitgevoer, veral na Wes-Duitsland.

Asbes:

Chrysotiel-asbes is in 1938 ontdek in die Havelockgebied en hierdie myn het sedertdien een van die vernaamste produseerders van asbes in die wêreld geword. Die voorkoms is in plaatagtige vorm in rotse van die Jamestown-kompleks wat ingedring het in die Figtree-serie. Die erts uord op die myneiendom bewerk en die vesels word in sakke verpak, en met 'n $12 \frac{1}{2}$ myl lange kabelspoor na Barberton versend.

Bariet:

Bariet is eers in 1937 in Swaziland ontdek, naby Oshoek. In 1945 is ' $n$ myn geopen ongeveer $2 \frac{1}{2}$ myl ten noorde van die Mbabane-Johannesburgpad op die oostelike hange van die Londosi-vallei. Die myn lewer sedert 1945 klein hoeveelhede bariet wat in die glas- en verfnywerhede gebruik word.

\section{Kaolien:}

Kaolien kom voor in die Mahlangatsha-gebied van die Mankaiana-distrik. Oor die oorsprong van hierdie Kaolien bestaan daar twyfel. Dit is voorgestel dat die verwerwing van suur gange die oorsaak kan wees. Daar word geskat dat daar $3,000,000$ kort ton kaolien tot 'n diepte van $50 \mathrm{vt}$. aanwesig is. Mynbedrywighede het aan die einde van 1961 'n aanvang geneem en 5813 ton is in daardie jaar geproduseer. 


\section{Steenkool:}

Die eerste steenkool is waarskynlik ongeveer 1877 in Swaziland ontdek. Verskeie mynkonsessies is al gemaak, maar geen grootskaalse mynaktiwiteite het nog plaasgevind nie, veral vanweë die afwesigheid van goeie vervoermiddels.

Die gebied suid van die Groot-Usuturivier is deur 'n mynmaatskappy ondersoek wat prospekteerregte vir hierdie streek verkry het. Daar is gevind dat in hierdie gebied eerstegraadse antrasiet voorkom.

As gevolg van hierdie prospekteeraktiwiteite het 2 groot mynmaatskappye verkenningskagte gegrawe. Ten tye van hierdie werksaamhede was daar nog nie sprake van 'n spoorweg nie en gevolglik is verkenningswerk gestaak, tot tyd en wyl vervoerfasiliteite verbeter het. Dit is te verwagte dat met die voltooiing van hierdie spoorweg 'n nuwe impetus aan die steenkoolbedryf sal verskaf.

Die steenkool kom voor in die Ecca-serie van die Karoosisteem in verskeie distrikte dwarsdeur Swaziland.

Pirofilliet:

Dit is 'n gehidreerde silikaat en kom baie ooreen met kalk, wat sy fisiese kenmerke betref.

Produksie van pirofilliet het in 1957 'n aanvang geneem en 'n totaal van 6,855.24 ton opgelewer tot aan die einde van 1961.

Daar kom ook 'n hele aantal minerale voor wat op hierdie stadium nie ekonomies ontgin kan word nie, o.a.:

Arseen; Kobalt; Lood; Mangaan; Kwik; Molibdeen; Nikkel; Yttrotantaliet (klein hoeveelhede konsentraat is in 1954 en 1956 uitgevoer); Tantalum; Thorium; Vanadium; Wolfram (Tungsten); Sink; Sirkoon; Kalsiet; Korumdum; Fluorspar; Grafiet; Helium; Magnesiet; Mika; Perliet; Kwarts; Swawel en Ysterpiriet; Talk; Vermiculiet.

DEEL II:

\section{DIE FISIESE GEOGRAFIE.}

1. Ligging en grootte:

A. Ligging:

1. Die land Swaziland word omsluit deur die $25^{\circ} 45^{\prime}$ en $27^{\circ}$ 
$15^{\prime}$ suiderbreedtelyne en die $30^{\circ} 45^{\prime}$ en $32^{\circ} 15^{\prime}$ oosterlengtelyne.

2. Die grootste deel van Swaziland word omring deur die R.S.A. met die Transvaal as die noordelike, westelike en suidelike grens, met 'n deel van die oostelike grens aan Natal en die res van die oostelike grens gevorm deur Mosambiek.

3. Manzini (vroeër Bremersdorp), lê met die pad langs 250 myl van Johannesburg, 340 myl van Durban en 120 myl van Lourenco Marques.

B. Grootte:

1. Swaziland beslaan 'n oppervlakte van 6,705 vk. myl $(4,291,000$ acre of $1,977,000$ morg $)$.

2. Die land het 'n baie kompakte vorm met 'n maksimum noord-suid strekking van 120 myl en 'n maksimum oos-wes strekking van 90 myl.

C. Administratiewe verdeling en grondbesit:

Kaart 1 toon die grondbesit in Swaziland waar die gebied met stippels bedek die eiendom van die Swazivolk is, terwyl die res die privaat eiendom van blankes, Kleurlinge en Bantoes aantoon. Die natrek toon die administratiewe verdeling van Swaziland in sy distrikte.

Tabel 4 toon die verdeling van grond in acre en ook as 'n persentasie van die totale landsoppervlakte uitgedruk.

TABEL 4.1)

Grondbesit in Swaziland op 31.12.1961.

Grondbesitter

Swazivolk

Nie-toegekende Kroongrond

Blanke en Kleurling privaat

eiendom (insluitende geproklameerde dorpsgebiede)

Swazi privaat eiendom

Eiendom van sendinggenootskappe

Regeringseiendom

Totale oppervlakte van gebied

$$
\begin{array}{cc}
\text { oppervlakte } & \text { \% van totale } \\
\text { in acres } & \text { oppervlakte } \\
2,224,482 & 51.84 \\
101,900 & 2.38
\end{array}
$$


Die gebied wat deur die Swazivolk bewoon kan word, beslaan 1,639,687 acre Bantoegebied; 268,093 acre land aangekoop deur die Swazivolk se Lifafonds en 316,702 acre Bantoenedersettingsgrond bestaande uit grond deur die regering gekoop asook toegekende Kroongrond.

Die Lifafonds is in 1946 gestig met die doel om addisionele grond aan te koop en om oorbeweiding te verminder. Volgens 'n bevel van die Ngwenyama word daar gereeld beeste uitgekeer van die troppe van Swazi's wat meer as 10 beeste besit. Hierdie diere word verkoop en ' $n$ heffing op die opbrengs word in die Lifafonds gestort.

Die Bantoenedersettingsgebied bestaan uit plase wat deur die Regering van blanke eienaars aangekoop is en Kroongrond deur die Regering toegeken.

In die Swazigebied word 'n sisteem van stam-grondbesit toegepas en word woon- en bewerkbare grond deur die kapteins toegeken in die gebied waaroor hulle gesag voer. Behalwe wanneer die bewoner die grond verlaat of hom skuldig maak aan sekere misdade o.a. toordery of egbreuk, wat ernstig genoeg beskou word vir verbanning, staan sy bewoningsreg vas. $\mathrm{Na}$ 'n vyftigjarige aanraking met die blanke se stelsel van grondbesit egter en ook weens die skaarste aan grond, word die bewoning nou meer permanent met die aksent op die individuele boerdery.

\section{Topografie:}

a) Kaart 2 toon die topografiese verdeling van Swaziland in vier duidelike fisiografiese streke, nl.:

i) Hoëveld (Inkangala): Dit het 'n gemiddelde hoogte van 3500-4500 voet bo seespieël, is die noordooswaartse voortsetting van die Drakensberge maar met dié verskil dat dit nie 'n aaneenlopende hoë eskarpement is nie maar eerder 'n gedissekteerde bergmassief met diep riviervalleie en klowe met hoë uitlopers. Die kruine van Emlembe (6120 voet) en Ngwenya (6005 voet) is die hoogste pieke in die gebied.

ii) Middelveld (Nguane - wat beteken Lewe - het geen spesiale Swazinaam nie en is die kern van die Stamgebied): Dit het 'n gemiddelde hoogte van 2000-2500 voet bo seespieël en is in sekere dele tog bergagtig. Dit begin as die geleidelik 
wyer wordende valleie van die hoëveld en gaan oor in die golwende graslandskap van die egte middelveld.

Vleie (seisoenmoerasse) kom algemeen voor en dongas weens gronderosie is 'n wesentlike gevaar indien grondbewaring nie toegepas word nie.

iii) Laeveld (Ihlanze): Dit is 'n geleidelik golwende laagland tussen geïsoleerde hoërliggende dele bv. Nkambeni (2380 voet), Dumezulu (2574 voet) en Nkondolo (2400 voet), wat die kenmerkende laagland-voorkoms onderbreek.

Malaria word sedert 1947 op 'n beplande grondslag deur die Regering bestry en in die 1962-jaarverslag ${ }^{2}$ ) word genoem dat 19,002 bloedplaatjies van Swazi's ondersoek is waarvan $0.34 \%$ positief was, terwyl uit 2923 plaatjies van immigrante $4.6 \%$ positief was.

Bilharzia kom algemeen voor en daar is bereken dat $30 \%$ van die Swazibevolking die siekte onder lede het, maar die eienaardige hiervan is dat „Bilharzia does not appear to be a significant cause of ill-health amongst the indigenous population". ${ }^{3}$ )

iv) Lebombo-plato: 'n Weswaartsgerigte indrukwekkende eskarpement vorm die oosgrens van die Laeveld en die wesgrens van die plato met sy geleidelike ooswaartse hellings vleuel. Die gemiddelde hoogte is $2000-2500$ voet bo die seespieël, wat ooreenstem met die Middelveld. Die landskap het 'n golwende voorkoms, maar is sterk gedissekteer deur diep valleie wat teruggevreet het tot teenaan die westelike eskarpement. Drie diep poorte (van noord na suid), Umbeluzi, Usutu en Ingwavuma vorm die deurgange van hierdie drie riviere deur die Lebombo-plato, maar verder strek hierdie plato ononderbroke van noord na suid deur Swaziland.

b) Soos later gesien sal word, het hierdie topografiese verskille; tesame met die geologie van die gebied; sy invloed op die klimaat, plantegroei, dreinering, gronde en uiteindelik op die menslike bedrywighede wat van hierdie geografiese elemente afhanklik is. Nogtans sal daar ook later gesien word dat die gebied met die grootste potensiaal vir toekomstige ontwikkeling oos-wes oor hierdie nood-suid strekkende streke lê, nl. die Mbabane Manzini-gebied. Die redes hiervoor sal later gestel word. 


\section{Dreinering:}

Swaziland is een van die gebiede wat die beste bedeeld is met water in die hele Suidelike Afrika. Byna al die strome in die hoëveld is standhoudend in teenstelling met die laeveld waar, alhoewel die stroomkanale groot is, hulle slegs na swaar reëns vol is en andersins uit droë lope en seekoeigate bestaan.

Die algemene stroomvloeirigting is ooswaarts en daar vloei van die Hoëveld die Lomati, Komati, Umbeluzi, Usushwane (Klein Usutu), Usutu, Ngwempisi en Mkondo. Elk van hierdie strome word gevoed deur talle sytakke uit die opvanggebiede.

Die gemiddelde jaarlikse afloop van die Usutu is ongeveer $2,000,000$ acre/voet en van die Komati ongeveer 900,000 acre/ voet. (Die gemiddelde jaarlikse afloop van die Vaalrivier by Vaaldam is $1,700,000$ acre/voet). Die Ingwavuma- en Umbeluziriviere is van minder belang. Eersgenoemde het al by geleenthede opgehou met vloei, maar gekonsentreerde herwinning en beskerming van die opvanggebied het reeds goeie vrugte afgewerp.

Hierdie waterrykdom van Swaziland vorm een van sy vernaamste natuurlike hulpbronne veral wat besproeiing, opwekking van hidro-elektriese krag en water vir nuwerheidsgebruik betref. Die steeds toenemende beskerming van die opvanggebiede deur die Regering is dus noodsaaklik om die afloop- en opvangvolumes van hierdie strome te bewaar.

\section{Klimaat:}

Die hoëveld het 'n humiede, byna gematigde klimaat met 'n gemiddelde reënval van tussen $40^{\prime \prime}$ en $90^{\prime \prime}$ per jaar. Die gemiddelde jaarlikse temperatuur is ongeveer $62^{\circ} \mathrm{F}$. Die seisoenstemperatuurspeling is ongeveer $20^{\circ} \mathrm{F}$. Die gemiddelde daaglikse speling is egter heelwat hoër, nl. $52^{\circ} \mathrm{F}$. Die voorkoms van mistigheid en wolke veroorsaak waarskynlik hierdie lae syfer.

Mbabane het in 16 uit die 25 jaar waarin rekords gehou is, ryp ondervind. Die gemiddelde aantal rypdae is egter slegs 22 dae per jaar, maar kan altyd in die winter verwag word. 
Die middelveld kan beskryf word as subtropies met 'n gemiddelde jaarlikse reënval van tussen $30^{\prime \prime}$ en $35^{\prime \prime}$. Die gemiddelde jaarlikse temperatuur is ongeveer $68^{\circ} \mathrm{F}$. met ' $\mathrm{n}$ seisoenstemperatuurspeling van ongeveer $24^{\circ} \mathrm{F}$. en 'n gemiddelde daaglikse speling van $54^{\circ} \mathrm{F}$.

Manzini het in die 14 jaar waaroor die rekords strek nooit ryp ondervind nie, maar effens verder suid by Dearn ( 500 voet hoër as Manzini) kom ryp in Junie en Julie gereeld voor. Die valleie is veral aan ryp onderhewig weens temperatuurinversie.

Die laeveld kan beskryf word as byna tropies en is definitief subhumied. Die gemiddelde reënval is tussen $20^{\prime \prime}$ en $30^{\prime \prime}$ per jaar. Die gemiddelde jaarlikse temperatuur is ongeveer $72^{\circ} \mathrm{F}$. en het 'n seisoenstemperatuurspeling van $61^{\circ} \mathrm{F}$. Ryp kom selde voor, alhoewel Balegane (in die noorde van Swaziland) wel ryp in Junie en Julie ondervind het. Balegane lê egter op die oewer van die Komatirivier.

In die Republiek word 'n gemiddelde reënval van 20" tot $30^{\prime \prime}$ per jaar as voldoende beskou vir die verbouing van meeste landbouprodukte. Die lae hoogte bo seespieël tesame met die hoë temperature sal egter 'n baie verdampingstranspirasiesyfer tot gevolg hê, wat dus die waarde van die reënval merkbaar sal verlaag en soos later onder die droogte-probleem gesien sal word, 'n ernstige belemmering word.

Die Lebombo-plato kan ook as subtropies beskryf word met 'n gemiddelde jaarlikse reënval van meer as $30^{\prime \prime}$. Die gemiddelde jaarlikse temperatuur is ongeveer $69^{\circ} \mathrm{F}$. en die seisoenstemperatuurspeling $20^{\circ} \mathrm{F}$. en 'n gemiddelde daaglikse speling van $42^{\circ} \mathrm{F}$. Hierdie laer gemiddelde temperatuurspelings word toegeskryf aan die feit dat die plato in die rigting van die Indiese oseaan hel, die nabyheid van die oseaan met sy matigende invloed, die hoër reënval en dus ook hoër wolkbedekking. Oor 'n tydperk van 15 jaar waarin rekords gehou is, het geen ryp op Stegi voorgekom nie. Die laagste daaglikse uiterste temperatuur wat aangeteken is, was $38.2^{\circ} \mathrm{F}$. Dat ryp egter kan voorkom, is nie uitgesluit nie.

Tabel 5 toon die gemiddelde maksimum en minimum reënval in duime vir stasies binne die streke. 
TABEL 5.

Gemiddelde, maksimum en minimum reënval vir stasies binne die vier streke (in duime).

\begin{tabular}{lccc}
\hline $\begin{array}{l}\text { Streek en } \\
\text { naam van } \\
\text { stasie }\end{array}$ & $\begin{array}{c}\text { Gem. jaarlikse } \\
\text { reënval } \\
\text { (duime) }\end{array}$ & $\begin{array}{c}\text { Maksimum } \\
\text { jaarlikse } \\
\text { reënval }\end{array}$ & $\begin{array}{r}\text { Minimum } \\
\text { jaarlikse } \\
\text { reënval }\end{array}$ \\
\hline $\begin{array}{l}\text { Hoëveld: } \\
\text { Havelock }\end{array}$ & 69.94 & 106.94 & 44.99 \\
Mbabane & 54.65 & 81.88 & 35.40 \\
Hlatikulu & 44.85 & 67.06 & 26.40 \\
Middelveld: & & & \\
Manzini & 35.64 & 63.08 & 19.21 \\
Kubuta & 30.79 & 54.33 & 12.51 \\
Goedgegun & 35.01 & 50.08 & 19.89 \\
$\begin{array}{l}\text { Laeveld: } \\
\text { Balegane }\end{array}$ & 28.71 & 43.07 & 13.87 \\
Big Bend & 20.83 & 32.83 & 11.53 \\
Gollel & 23.38 & 33.60 & 7.93 \\
Lebombo: & & & \\
Stegi & 33.59 & 59.63 & 14.40 \\
\hline
\end{tabular}

Die verspreiding van die jaarlikse reënval is sodanig dat $75 \%$ tot $80 \%$ van die totaal gedurende die maande Oktober tot Maart voorkom - dus 'n ware somerreënvalstreek.

Maar net so belangrik as wat temperatuuruiterstes vir die verbouing van landbougewasse is - hoë temperature lei tot verskroeiing en lae temperature tot ryp-skade - net so belangrik is die betroubaarheid van die reënval vir die verbouiing van landbouprodukte en die veeboerdery.

As die gemiddelde jaarlikse reënvalkaart met die droogtegevaarkaart vergelyk word, vind ons dat die grootste gevaar vir droogte ondervind word in die dele waar die reënval die laagste is en dat die minste gevaar bestaan in die dele waar die reënval die hoogste is. 
Die droogtegevaar-kaart toon die persentasie somers (Oktober tot Maart) waarin die reënval laer as $25^{\prime \prime}$ per jaar is.

Die syfers vir die streke is ongeveer soos volg:

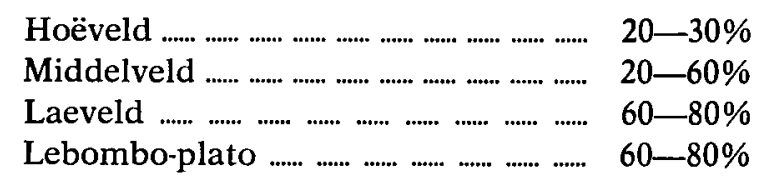

Die veranderlikheid van die reënval van jaar tot jaar is hoog, veral in die laeveld waar 'n jaarlikse reënval van $30^{\prime \prime}$ slegs in een tot twee jare uit tien verwag kan word in vergelyking met vyf of meer jare uit tien in die ander gebiede.

Die oppervlakte van Swaziland (vk. myl) wat 'n gemiddelde reënval tussen die getoonde limiete kry is soos volg:

$\begin{array}{cc}\text { Reënval (duime) } & \text { Oppervl. (vk. myl) } \\ 20-25 & 780 \\ 25-30 & 1370 \\ 30-35 & 1500 \\ 35-40 & 1340 \\ 40-50 & 1000 \\ 50-60 & 560 \\ 60-90 & 150\end{array}$

$32 \%$ van Swaziland ontvang dus meer as 30 " reën per jaar en is dit hoofsaaklik die laeveld wat die droogteprobleem ondervind.

Dit is interessant om nou reeds daarop te let dat die grootste deel van die besproeide gronde tog in hierdie droë laeveld voorkom waar veral suiker, rys, katoen en sitrus verbou word. Hierdie produkte is egter baie gevoelig vir die laer temperature van die hoërliggende dele.

Die temperatuuruiterstes $\left({ }^{\circ} \mathrm{F}\right.$.) wat by die verskillende stasies binne die verskillende streke geregistreer is, word in Tabel 6 aangetoon en kan beperkend wees vir die verbouing van sekere produkte volgens die vereistes van elke produk en ook in vergelyking met die optimum vereistes van die gewas. 
TABEL 6.

Temperatuuruiterstes $\left({ }^{\circ} \mathrm{F}\right.$.) by verskillende stasies binne die streke.

\begin{tabular}{lrccc}
\hline $\begin{array}{l}\text { Streek } \\
\text { en stasie }\end{array}$ & $\begin{array}{c}\text { Absolute } \\
\text { maksimum } \\
\text { temp. }\end{array}$ & $\begin{array}{c}\text { Gemid. } \\
\text { maksimum } \\
\text { temp. }\end{array}$ & $\begin{array}{c}\text { Absolute } \\
\text { minimum } \\
\text { temp. }\end{array}$ & $\begin{array}{c}\text { Gemid. } \\
\text { minimum } \\
\text { temp. }\end{array}$ \\
\hline Hoëveld: & & & & \\
Havelock & 96.0 & 72.6 & 30.1 & 53.2 \\
Mbabane & 100.9 & 72.8 & 20.8 & 51.6 \\
Hlatikulu & 99.5 & 70.3 & 27.0 & 52.8 \\
Middelveld: & & & & \\
Manzini & 108.9 & 79.2 & 32.0 & 56.4 \\
Kubuta & 108.5 & 78.6 & 31.0 & 58.9 \\
Goedgegun & 96.4 & 75.3 & 21.6 & 53.6 \\
Laeveld: & 108.5 & 83.6 & 29.3 & 57.8 \\
Balegane & 108.4 & 84.5 & 32.0 & 59.8 \\
Big Bend & 112.0 & 83.9 & 29.0 & 60.9 \\
Gollel & & & & \\
Lebombo: & 120.3 & 76.8 & 27.1 & 57.0 \\
Stegi & & & & \\
\hline
\end{tabular}

Die temperature van die gebied kan dus in die somer baie hoog word terwyl die wintertemperature, met uitsondering, nie as besonder laag beskou word nie.

Binne die beperkings deur elke grens gestel, behoort temperatuur nie ' $n$ ernstige beperkende faktor te wees nie, maar die reënval in die geval van droëlandgewas-verbouing sal 'n definitiewe beperke faktor vorm. Die enigste oplossing is besproeiing, wat dan ook waar moontlik in toenemende mate toegepas word.

Hael is 'n klimaatselement wat wel voorkom en soos by die Ngonini Citrus Estates gesien is, word dit met vuurpyle bestry. 


\section{Plantegroei:}

'n Vergelyking van die plantegroeikaart (Kaart 4) met die topografiese kaart (Kaart 2) en ook die gemiddelde reënvalkaart (Kaart 3) toon die baie noue ooreenkoms van die plantegroeiverspreiding met die topografie en reënval. As die grondkaart (Kaart 5) ook hiermee vergelyk word, word die ooreenkoms nog duideliker en moet dit sekerlik nie as merkwaardig beskou word nie maar slegs weer aantoon dat die edafiese (grond) en klimaat (veral reënval en temperatuur, laasgenoemde weens die topografie) die plantegroeibedekking in die natuurlike habitat lokaliseer.

Die natuurlike plantegroei wat in die vier fisiografiese streke voorkom, is hoofsaaklik die volgende:

\section{a) Die Hoëveld:}

Berg- en Hooglandsuurveld: Dit bestaan uit kort grasveld op die hoër onbeskutte hellings met woude in die beskutte klowe en kleiner bome tussen die granietblokke en op die puinhellings. Die bome in die woude word tot $60 \mathrm{vt}$. hoog met 'n digte struikgewas en varings. Die gras is hoofsaaklik Themeda, Andropogon, Tristachya en Eragrostis.

Die Hoëveld is ' $n$ besondere gebied vir woude soos die Usutu-woud dan ook toon. Die grasse is egter hoofsaaklik suur en het dus ' $n$ lae voedingswaarde in die winter met gevolglike oorbeweiding, sodat die drakrag van die veld gou oorskry word met die gevolglike vernietiging van die plantbedekking.

Dit is egter 'n goeie winterweidingstreek vir skape, soos later gesien sal word.

\section{b) Middelveld:}

Hoogliggende en middelveld-langgrasveld: Eersgenoemde deel bestaan uit oop grasveld met hoofsaaklik Tristachya, Trachypogon en Themeda grassoorte. Die ware middelveld is Savanne met verspreide Acacia tussen die Hyparrhenia-Eragrostis grassoorte.

Veldbrande, landbou en oorbeweiding het die veld al heel- 
wat verswak. Weiding is egter beter as in die Hoëveld, maar ook hier is oorbeweiding ' $n$ probleem en in die laer middelveld is die inname van die veld deur doringbosse ' $n$ ernstige probleem.

\section{c) Die Laeveld:}

Drie plantegroeistreke word in die laeveld onderskei wat gekenmerk word deur 'n groot verskeidenheid verspreide bome. In die Swazi-gebied veral is die bome baie uitgekap en is die vernaamste plantegroei gras, wat in baie dele baie verswak is deur oorbeweiding en veldbrande.

Die drie plantegroei-substreke is:

i) Laeveldse bladwisselende bosse: Hoë grasse van die Hyparrhenia, Aristida en Perotis kom onder die Combretum, Sclerocarya, Dickrostachys en Acacia-bome voor.

ii) Laeveldse Acacia-Savanne (Soetveld): Dit is oop Acacia en Scerocarya-parklandskap met Themeda-, Aristida- en Urochloa-soetgras. Acacia- en Dichrosthachys-bosse kom voor waar die veld oorbewei is.

iii) Ariede Laeveld (Soetveld): Dit is 'n oop Acacia- en Sclerocarya-parklandskap met Digitaria-, Schima-, en Themedagrastipes. Waar die grond swaar is, kom digte Acacia-doringveld voor. Die "Soetveld" het 'n baie hoë voedingswaarde maar die gebrek aan suiping vir die diere is 'n probleem.

\section{d) Die Lebombo-plato:}

Die plato word hoofsaaklik beslaan deur:

i) gemengde bosveld wat uit digte Acacia-doringveld afgewissel met oop polplantegroei insluitend Ficus-Combretum bestaan. Die gras is dikwels Themeda-Panicum;

ii) die Laeveldse Acacia-Savanne (Soetveld) kom veral aan die laerliggende oostelike hellingsvleuel en in die riviervalleie voor. Hierdie plantegroeitipe is reeds onder die laeveld bespreek.

Die grasveld is dus meesal geskik vir beweiding omdat daar heelwat soetgrastipes voorkom maar oorbeweiding, veldbrande en gebrek aan seisoensrus deur kampe lei tot die voorkoms van steekgrassoorte. 


\section{a) Grondklassifikasie en navorsing:}

Aan die einde van 1962 was daar reeds 568,000 acre of $13 \%$ van Swaziland se gronde gekarteer.

Hierdie navorsing, wat deur mnr. G. F. M. Murdoch uitgevoer word, volg die prosedure om eers te besluit op die gewasaanplantingsisteem van die gebied. Die hellingskategorieë word van die topografiese kaarte bepaal, die grondgrense word van lugfoto's in die veld vasgestel en aan elke serie word 'n ,gewasklassifikasie" toegeken volgens die voorgestelde gewasaanplantingsisteem. Die hellingskategorie en gewasklassifikasiekaart word dan gekombineer om 'n landsgebruik-potensiaal. kaart te verkry.

Hierdie metode van bepaling van landsgebruikpotensiaal van die gebied deur ook die helling van die grond in berekening te bring tesame met die grondsoorte, lei tot 'n heelwat duideliker begrip van die gronde as slegs 'n meesal onbruikbare chemiese klassifikasie.

Steeds meer gedetaileerde kaarte van gronde word opgestel soos in die voorbeeld getoon. (Kaart A). Hierdie kaarte word eerstens saamgestel vir die gebiede waar die landboupotensiaal die werk regverdig. (Kaart $\mathrm{A}$ is nie ingesluit nie).

'n Vereenvoudigde grondkaart (Kaart 5) toon 'n sterk ooreenkoms met die geologiese en die fisiografiese kaarte (Kaarte B 1 en 2 respektiewelik). Kaart B is nie ingesluit nie.

a) Die hoëveldse gronde is hoofsaaklik diep-rooi, oranje en geel gronde met 'n medium tekstuur en goeie fisiese eienskappe. Al die gronde is suur, maar waar die hellings van die hange minder as $8^{\circ}(14 \%)$ is, word goeie landboupotensiaal gevind indien van dolomitiese landboukalk gebruik gemaak word.

Hierdie suur gronde, aluminiumsilikate - dus kaolisols is veral die rooi- en geel-ysterhoudende tipes en ontstaan hoofsaaklik uit die graniete en kwartsiete wat op die hoëveld voorkom.

b) Die middelveldse gronde word hoofsaaklik onderlê deur graniet; gneiss, doleriet, kwartsiete en ander rotstipes kom minder uitgebreid voor.

Die vernaamste grondsoorte is diep krummelrige rooi leemgronde en klei-leem, en waar die dreinering swak is, kom 
grys-bruin sande en sanderige leemgronde voor. 'n Harde pan van yster-konkresies onderlê oor die algemeen die gronde.

Hierdie gronde is meesal ook suur en slegs in sekere dele baie vrugbaar, maar meesal redelik vrugbaar tot swak. Die toepassing van grondbewaringspraktyke en besproeiing het sekere dele van die middelveld die besondere ontwikkelingsgebied gemaak.

c) Die laeveld kan algemeen in twee streke verdeel word volgens die onderliggende geologiese formasies, nl. die suur rotse in die westelike laeveld (graniet, steenkooldraende Eccasandsteen en skalie) en die basiese rotse van die oostelike laeveld (basalt en doleriet).

Die gronde word in hierdie patroon weerspieël, nl. dat dit in die westelike laeveld met die van die middelveld ooreenstem en hoofsaaklik suur gronde is, pesendopodsolities en halomorfies, maar nie brak nie. Die gronde in die oostelike laeveld is vlakker rooi en swart klei (swart turf). Laasgenoemde is die vrugbaarste gronde van die gebied, maar net soos in Transvaal moeilik om te bewerk as die voggehalte nie presies reg is nie.

d) Die Lebomboplato bestaan hoofsaaklik uit suur tot intermediêre vulkaniese lawas, insluitende rioliet en die gronde wat op die plato voorkom is taamlike diep, rooierige, medium tot swaar suur gronde wat met die van die middelveld ooreenkom. Hierdie gronde is egter beperk tot die Stegi- en Nomahasha-omgewings. Die orige deel van die Lebombo word beperk deur hun grondbedekkings wat in baie dele selfs ontbreek en uit rotsblokke en rotspuin bestaan, weens die hoë weerstand van hierdie rotse teen verwering.

Op die vereenvoudigde grondkaart (Kaart 5) word ook die gebiede getoon wat as onbruikbaar beskou kan word weens òf die rotsdagsome en rotspuin òf die dun grondlaag (skeletal soils).

As ons nou hierdie kaart (Kaart 5) bestudeer saam met Kaart 6 oor die landsgebruikpotensiaal, wat die grondpotensiaal, die helling van die gebied en die gemiddelde jaarlikse reënval inkorporeer, kry ons 'n idee van watter deel van Swaziland vir landbou geskik is en watter dele ook die beste moontlikhede vir ontwikkeling bied. 
Die beste gronde met hellings van minder as $8^{\circ}(14 \%)$ en ' $n$ gemiddelde jaarlikse reënval van meer as 30 " per jaar beslaan 108,800 acre en is dus geskik vir droëland-boerdery. Die gebied met die beste gronde en hellings van minder as $8^{\circ}$ maar met 'n gemiddelde reënval van minder as $30^{\prime \prime}$ per jaar en wat dus besproeiing vir meeste gewasse vereis, beslaan 19,200 acre.

Die gebiede met 'n reënval bo $30^{\prime \prime}$ lê op die hoëveld en in die Lebomboplato-gebied, terwyl die gebied waar besproeiing toegepas moet word in die laeveld geleë is.

Daar is egter nog 512,000 acre waar die grond swakker is, maar die helling minder as $8^{\circ}$ en die reënval bo $30^{\prime \prime}$ per jaar, en ook 1,056,000 acre waar die gronde swakker is, die reënval minder as $30^{\prime \prime}$ per jaar maar die helling onder $8^{\circ}$ is.

Daar is verder ook 2,304,000 acre waarvan die grond swak is, die helling meer as $8^{\circ}$, dog die gemiddelde jaarlikse reënval meer as $30^{\prime \prime}$; terwyl 288,000 acre swak gronde het, hellings van meer as $8^{\circ}$ en 'n gemiddelde jaarlikse reënval van minder as $30^{\prime \prime}$ het.

Uit hierdie opsomming van die landsgebruik-potensiaal kan ons dan aflei dat Swaziland gebiede met die volgende potensiaal besit:

Hoog (droë land en besproeiing) …............................ $\quad 3 \%$

Redelik hoog (droëland) ............................................ $12 \%$

Redelik hoog (besproeiing is nodig) .............................. 25\%

Laag (hoofsaaklik droë land) ........................................ $60 \%$

Dit geld egter slegs van landbougewasse in die algemeen en daar moet op gelet word dat sekere gewasse ook ander vereistes soos temperatuur en bepaalde grondstruktuur en samestelling vereis.

So ook is die gebiede waar bosbou die beste ontwikkel is buite die gebiede met die beste gronde, maar het sy verspreiding slegs in die hoëveldse gebied waar woude vroeër goed ontwikkel was in 'n plantegroeiklimaks en die gebied aan die vereistes vir boomgroei voldoen.

7. Natuurlike hulpbronne van die natuurlike streke:

Die voorafgaande kaart (landsgebruik) kan egter nog nie die potensiaal van Suaziland se hulpbronne weergee nie, der- 
halwe is die natuurlike hulpbronne soos hulle in die verskillende natuurlike streke voorkom op die volgende kaart (Kaart 7) aangetoon.

Die natuurlike hulpbronne van die verskillende natuurlike streke kan soos volg opgesom word:

a) Die Hoëveld:

i) Die veld is nie sonder bykomende wintervoer geskik vir beeste nie. Dit is egter baie goeie winterweiding vir skape.

ii) Daar is feitlik geen aaneenstrekkende goeie landbougronde nie.

iii) Dit is uitstekend vir grootskaalse bosbou-aanplanting, veral denne, bloekom en wattel.

iv) Die strome van die hoëveld is almal standhoudend en dit is die waterrykste deel van Swaziland.

v) Die minerale rykdom van die Hoëveld is die belang. rikste in Swaziland, nl. asbes (Havelock), ystererts en bariet (Bomvu), asook goud, tin, kaolin, aluminiumsilikaat, diaspoor en laegraadse ystererts.

b) Die Middelveld:

i) Goeie beeswêreld weens beter weiding.

ii) Goeie landbougrond, wat op plekke besproei kan word, dog van beperkte omvang is. Die gebied is veral geskik vir sub-tropiese vrugte en rus.

iii) Aanvullende droëlandoeste by beesboerdery is moontlik, bv. mielies, kafferkoring en katoen.

iv) Geskikte plekke vir die oprigting van 'n hidro-elektriese kragsentrale in die Groot Usutu-rivier bestaan by Edwaleni.

c) Die Laeveld:

i) Dit is die beste weidingstreek van Swaziland weens die Soetgras wat voorkom. Hierdie potensiaal is egter tot 'n groot mate vernietig.

ii) Besproeiing van die goeie landbougronde is moontlik vir die intensiewe verbouing van suiker en rys.

iii) Katoen aard goed op droëland.

iv) Bitumeneuse steenkoolafsettings kom voor by Mpaka en antrasiet naby Maloma in die suide. 
d) Die Lebomboplato:

Weens die klein omvang van goeie landbougronde is dit hoofsaaklik 'n ekstensiewe beesboerdery-gebied.

Kaart 8 toon die huidige ontwikkeling van die potensiaal van Swaziland.

Die ontwikkeling van die natuurlike hulpbronne van Swaziland het in werklikheid eers aan die Tweede Wêreldoorlog begin en die vyftiger jare het die eintlike sprong na ontwikkeling gekenmerk.

Die vraag wat na vore kom, is waarom hierdie ontwikkeling so lank vertraag is?

Die politieke, internasionale en die ekonomiese oorwegings hiervoor sal nie bespreek word nie maar wat die geograaf betref, het die volgende oorwegings sekerlik bygedra tot die vertraging van die ontwikkeling.

a) 'n Gebrek aan kennis van die potensiaal van die gebied, en die algehele gebrek aan navorsing om die landbou 'n wetenskaplike bedryf te maak. Vandag word navorsing egter by verskeie navorsingstasies i.v.m. landbou en veeteelt onderneem.

b) Gebrek aan kapitaalkrag binne die land self asook die klein bydrae deur die Britse Regering deur sy British Colonial Development Fund, wat gedurende die tydperk 1929-1940 slegs R248,000 bygedra het in vergelyking met 'n bedrag van $\mathrm{R} 4,420,000$ van 1945-1958. Die belegging deur die privaatsektor is hierdeur gestimuleer bv. Anglo American Corporation en Courtaulds. Vroeër kon kapitaal ook nie gelok word nie, weens die algehele gebrek aan primêre dienste.

c) Swaziland is swak geleë t.o.v. die hoof-verbindingsrigtings van die ontwikkelingsgebiede wat dit omring. Die verbindingstrook Suid-Transvaal-Durban gaan suid van Swaziland verby, terwyl die Suid-Transvaal-Lourenco Marques verbindingstrook noord van Swaziland verby strek. Oos-Transvaal het min groot dorpe en 'n laer ontwikkelingspeil as Suid-Transvaal asook min natuurlike hulpbronne wat ontwikkel word en met die twee verbindingstroke skakel. Swaziland lê dus eintlik afgesny van die hoof-bevolkingsentra waar nywerheid en handel sterk ontwikkel is en was dus tot isolasie gedoem.

d) Die belangrikste gebiede van Swaziland was weens die 
topografiese geaardheid van die land onderhewig aan vervoeren verbindingsprobleme en die ontwikkelingsgebiede was in hoofsaak op vervoer deur privaat-ondernemings maar veral op die padmotordienste van die S.A.S. en H. aangewese.

In die noorde was Komatipoort, Hecktorspruit en Barberton die naaste spoorwegaansluiting, in die ooste Breyten en Ermelo en in die suide Piet Retief en Gollel.

Die spoorweg nou in aanbou van Bomvu Ridge na Goba sal dus die eerste spoorweg in die gebied self wees. (Gedeeltelik gefinansier deur ondernemings in die R.S.A.).

Green en Fair bepleit verbindings met Suid-Transvaal en Natal, omdat hier sulke belangrike markte vir Swaziland bestaan. ${ }^{4}$ )

e) Die natuurlike hulpbronne kom ook gelokaliseerd en verspreid in die hele gebied voor, sodat die ontuikkeling van die gebied bemoeilik word met ' $n$ oneweredige verspreiding van ontwikkeling wat nie beperk is tot 'n enkele natuurlike streek of ' $n$ bepaalde gebied nie.

f) Al die groot uitbreidings in die mynwese, bosbou, landbou en besproeiing, nywerheid en handel is beperk tot die blanke bewoonde gebiede en is in vier hoofgebiede gekonsentreer, nl. Mbabane-Manzini-gebied; Piggs Peak-Lomati-gebied; Tshaneni-Hlume-gebied; Ubombo-Big Bend-gebied. Die suidweste of Goedgegun-Mankaiana-gebied is baie swakker ontwikkel.

Die Swazi-bewoonde gebied het die stamgewoontes nagevolg met landbou en veeteelt as bedryf om slegs in hulle eie lewensbenodigdhede te voorsien, maar die intensiewe landbouopvoedkundige voorligting en opvoeding, die toenemende kapitaal-invloei, skepping van plaaslike en buitelandse markte, behoort ook die Swazi-gebiede te stimuleer om hierdie agterstand teenoor die blankebewoonde gebiede te verminder. Namate die lewensbehoeftes en -vereistes van die Swazi toeneem, kan so 'n ontwikkeling dan ook sekerlik verwag word.

Die agterstand van die Swazi wat betref sy kennis i.v.m. moderne metodes van bestuur en administrasie, finansies, tegniese en professionele dienste, asook gebrek aan vakmanne sal egter nie so maklik ingehaal kan word nie en sal daar nog op die kennis van die blanke staat gemaak moet word. 
g) Die gebrek aan voldoende krag vir die ontwikkeling van 'n nywerheidskompleks kan as 'n besonder belangrike faktor beskou word waarom nywerhede eerder na ander ontwikkelingstreke gegaan het as om hulle in Swaziland te vestig.

h) Die toename van blankes in Swaziland van 3,201 in 1946 tot 8,040 in 1962 het 'n belangrike rol gespeel in die versnelde ontwikkeling van Swaziland.

\section{DEEL III:}

\section{MENSLIKE NEDERSETTING EN BEDRYWIGHEDE:}

1. Bevolking:

\section{A. Bevolkingstatistiek:}

Die totale bevolking van Swaziland, 280,300 persone, is ongeveer dieselfde as die totale stedelike bevolking van Port Elizabeth (Sensus 1960); terwyl die totale blanke bevolking van Swaziland 8040 persone, ongeveer met die blanke stedelike bevolking van Witbank (Sensus 1960) ooreenstem. Daar is slegs 10 Indiërs in die gebied woonagtig.

Tabel 7 toon die bevolking van Swaziland vir sekere sensusjare onderverdeeld volgens die rasse-samestelling.

TABEL 7.5)

Bevolking van Swaziland volgens ras vir sekere sensusjare.

\begin{tabular}{lrrrrr}
\hline Ras & 1904 & 1921 & 1946 & 1956 & 1962 \\
\hline Bantoes & 84,529 & 110,295 & 181,269 & 233,214 & 270,000 \\
Kleurlinge & 72 & 451 & 745 & 1,378 & 2,260 \\
Blankes & 890 & 2,205 & 3,201 & 5,919 & 8,040 \\
\hline Totaal & 85,491 & 112,951 & 185,215 & 240,511 & 280,300
\end{tabular}

Die Bantoes vorm $96.2 \%$, die Kleurlinge $0.8 \%$ en die blankes $3 \%$ van die bevolking in 1962.

Gedurende die dekade 1946-55 was die bevolkingstoename $2.8 \%$ per jaar, dog sedert 1955 het die gemiddelde toename afgeneem na $2.4 \%$ per jaar. 
B. Bevolkingverspreiding:

i) Stedelike en plattelandse bevolkingsyfers.

Die stedelike bevolking was in 1962 in tien gebiede saamgetrek, waarvan ses geproklameerde woongebiede met hul buitestedelike omstreke is en die ander vier bevolkingskerne is, nl. twe suikermeulens, die Usutu-papierpapmeul en die Havelock-asbesmyn.

Die stedelike bevolking van hierdie tien nedersettings is 47,800 persone of $17 \%$ van die Swazilandse totaal. Van die rastotale in Tabel 4 gegee, vorm $15 \%$ van die Bantoe $(41,000$ persone), $69 \%$ van die blankes (5,570 persone) en $55 \%$ van die Kleurlinge (1,240 persone) die stedelike bevolking.

Ons vind dus 'n stedelike rassesamestelling van $85 \%$ Bantoe, 12\% Blankes en 3\% Kleurlinge.

Tabel 8 toon die totale (geronde syfer) en bevolkingsverdeling volgens ras in die tien stedelike gebiede van Swaziland.

\section{TABEL 8.}

Die totale bevolking en verdeling volgens ras van die stedelike gebiede van Swaziland.

\begin{tabular}{lrrrr}
\hline Stedelike gebied & Blank & Kleurling & Bantoe & Totaal \\
\hline Mbabane & 1790 & 300 & 6300 & 8400 \\
Manzini & 1320 & 400 & 6100 & 7800 \\
Stegi & 240 & 270 & 2900 & 3400 \\
Goedgegun & 300 & 60 & 1600 & 2000 \\
Piggs Peak & 150 & 20 & 1700 & 1900 \\
Hlatikulu & 120 & 50 & 1000 & 1200 \\
Tshaneni-Mhlume & 380 & 90 & 5900 & 6400 \\
Big Bend-Ubombo & 320 & 40 & 5800 & 6200 \\
Usutu Pulp & 390 & 0 & 5700 & 6100 \\
Havelockmyn & 560 & 10 & 4000 & 4600 \\
\hline
\end{tabular}

Die plattelandse bevolking van Swaziland beloop 232,500 
persone of $83 \%$ van die Swazilandse totaal. Van die totale in Tabel 7 aangegee, vorm dus $85 \%$ van die Bantoe $(229,000$ persone), $31 \%$ van die blankes ( 2470 persone) en $45 \%$ van die Kleurlinge (1020 persone) die plattelandse bevolking.

Die plattelandse rassesamestelling is dus $98.5 \%$ Bantoes, $1.1 \%$ blankes en $0.4 \%$ Kleurlinge.

Dit moet verder genoem word dat $70 \%$ van die totale bevolking, meer as 196,000 persone - byna almal Swazi's in $52 \%$ van Swaziland woon, nl. die Swazigebied.

\section{ii) Bevolkingsverspreiding en digtheid:}

Die bevolkingsverspreidingkaart (Kaart 9) met die grondbesit natrek, gee hierdie patroon baie duidelik weer en ons sien dat op die privaat bewoonde plase daar 'n baie kleiner bevolkingsametrekking is as in die Suazigebied, nl. 35,000 persone teenoor 196,000 persone respektiewelik. Uitgedruk as bevolkingsdigtheid per vk. myl 'n syfer van 12 teenoor 60 .

Die ligging van die tien stedelike gebiede word ook op die kaart aangetoon.

Die kaart toon ook die ongelyke verspreiding van die bevolking met bevolkingskonsentrasies in die plattelandse gebiede waar die moontlikhede van intensiewe landbou die grootste is, nl. die Lomativallei, Ezulwini-Malkerns-Untilanegebied en Goedgegun-Dwaleni in die middelveld asook die Nomahasha- en Stegi-gebiede in die Lebombostreek.

Uit die bespreking van die potensiaal en hulpbronne van die vier natuurlike streke van die gebied en ook die vier hoofontwikkelingstreke kan ons die volgende bevolkingsdigtheidspatroon verwag het.

Hoëveld (steil hellings beperkend op landbou) 46 pers./vk. myl Middelveld (beste landboustreek) 58 pers./vk. myl Laeveld (lae en onbetroubare reënval) Lebombo (rotsagtig met swak gronde) 27 pers./vk. myl Swaziland

Hierdie regionale verspreidingsdigtheid is afgelei uit Tabel 9 wat die bevolking volgens distrikte en die natuurlike streke aantoon. 
TABEL 9.

Bevolkingsverspreiding volgens distrikte en natuurlike streke.

\begin{tabular}{|c|c|c|c|c|c|c|}
\hline $\begin{array}{l}\text { 葍 } \\
\text { 品 }\end{array}$ & 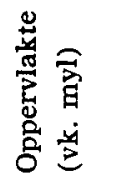 & 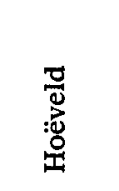 & $\begin{array}{l}\frac{\pi}{0} \\
\frac{\pi}{\pi} \\
\frac{\pi}{\pi} \\
\frac{\pi}{2}\end{array}$ & 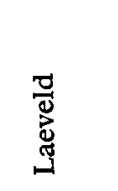 & 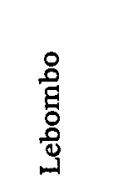 & 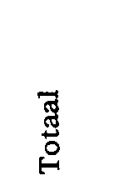 \\
\hline Hlatikulu & 1,870 & 16,200 & 41,800 & 21,000 & 300 & 79,300 \\
\hline Mankaiana & 900 & 30,700 & 6,300 & 200 & - & 37,200 \\
\hline Manzini & 1,000 & 1,700 & 39,400 & 12,300 & - & 53,400 \\
\hline Mbabane & 800 & 32,100 & 5,500 & - & - & 37,600 \\
\hline Piggs Peak & 630 & 11,300 & 16,800 & 3,500 & - & 31,600 \\
\hline Stegi & 1,500 & - & 400 & 25,400 & 15,400 & 41,200 \\
\hline \multicolumn{2}{|l|}{ Swaziland } & 92,000 & 110,200 & 62,400 & 15,700 & 280,300 \\
\hline \multicolumn{2}{|c|}{ Oppv. (vk. myl) } & 2,000 & 1,900 & 2,300 & 500 & 6,700 \\
\hline \multicolumn{2}{|c|}{ Bevolkingsdigtheid } & 46 & 58 & 27 & 31 & 41 \\
\hline
\end{tabular}

Die bevolkingskonsentrasies hang natuurlik ook saam met die ontginning van minerale, en ons kan dus verwag dat daar 'n groot toename in die laeveld sal kom sodra die ontginning van steenkool by Mpaka 'n aanvang neem, in die hoëveld by Bomvu Ridge sodra die ystererts ontgin word, asook die toename van die stedelike bevolking in die woongebiede waar nywerheidsontwikkeling en uitbreiding van dienste kom. Ten laaste sal die toenemende besproeiingsgronde wat oopgestel word en die uitbreidings by die suikermeulens hierdie konsentrasies verder verhoog, in die middelveld maar veral in die laeveld.

\section{Arbeidsverdeling:}

Totdat die naoorlogse ontwikkelingsperiode ingetree het, was die goudmyne van die R.S.A. die hoof-arbeidskring van die Swazi's. In Swaziland self was die Havelockmyn en die blanke-bewoonde plase die hoof-werkverskaffers. Die Usutu- 
papiermeul, die twee suikermeulens en kleiner nywerhede bv. die inmaakfabriek by Malkerns, rys- en graanmeulens by Manzini en sitrusverpakking het nuwe werkgeleentheid verskaf. Die uitbreiding by Bomvu Ridge, die bou van die spoorlyn, die hidro-elektriese kragsentrale, aanlê van paaie en grondbewaringsprojekte dra ook hiertoe by.

Die „Social Survey”-syfers van 1960 toon dat die Swazi's steeds afhankliker word van 'n loon-inkomste en het in 1960 al $20 \%$ van die inkomste van die Swazi-huisgesin uitgemaak met insluiting van die bestaans-boerdery.

Dit is bereken dat van die plattelandse manlike Bantoebevolking verdien $40 \%$ 'n loon, $45 \%$ het nie op die tydstip loon verdien nie maar was vroeër werknemers, terwyl $15 \%$ nooit werknemers was nie. Die ooreenstemmende syfers vir die stedelike manlike Bantoebevolking is $70 \%$ in diens, $21 \%$ nie tans in diens nie en $9 \%$ was nog nooit in diens gewees nie.

Daar is dus nog ' $n$ geweldige werkerspotensiaal beskikbaar in Suaziland, maar weens die feit dat die gemiddelde Swaziman slegs $40 \%$ van sy tyd in loongewende werk deurbring, dic feit dat hy 'n ongeskoolde arbeider is en die lae kwaliteit van die gelewerde werk bring mee dat slegs baie onderwys, tegniese onderrig en praktiese ondervinding deur aaneenlopende arbeid in dieselfde betrekking die optimum aanwending van hierdie arbeidspotensiaal sal kan verseker.

\section{Menslike bedrywighede:}

(Hierdie deel word slegs oorsigtelik behandel omdat in die volgende referaat hierdie aspek in meer besonderhede behandel sal word).

Die benutting van die natuurlike hulpbronne van die gebied en die mate waarin die potensiaal reeds deur die bewoners van Swaziland benut is, word in die produksiesyfers en aktiviteit van die mens in die gebied weerspieël.

In 1962 was die landsgebruikpatroon van Swaziland soos volg:

Landsgebruik

Acre

$\%$

Permanente weiding (insluitend 400,000 acre rotsagtige dele en 
280,000 acre seisoensmoerasse)

$3,170,000$

Landbougrond (40,000 acre word

besproei en byna die helfte lê braak)

590,000

14

Woude en bosse $(220,000$ acre

aangeplant en res inheems)

$320,000 \quad 8$

Nie-landbougrond

210,000

Totaal

$4,290,000$

A. Landbou:

Tabel 10 toon die produksiesyfers in acre geplant of gesaai, die oes in tonne, die gemiddelde opbrengs in pond per acre, asook die waarde van die oes in Rand en die waarde in Rand van die deel van die oes wat uitgevoer is. Die syfers is vir die seisoen Sept. 1961-Aug. 1962.

TABEL 10.

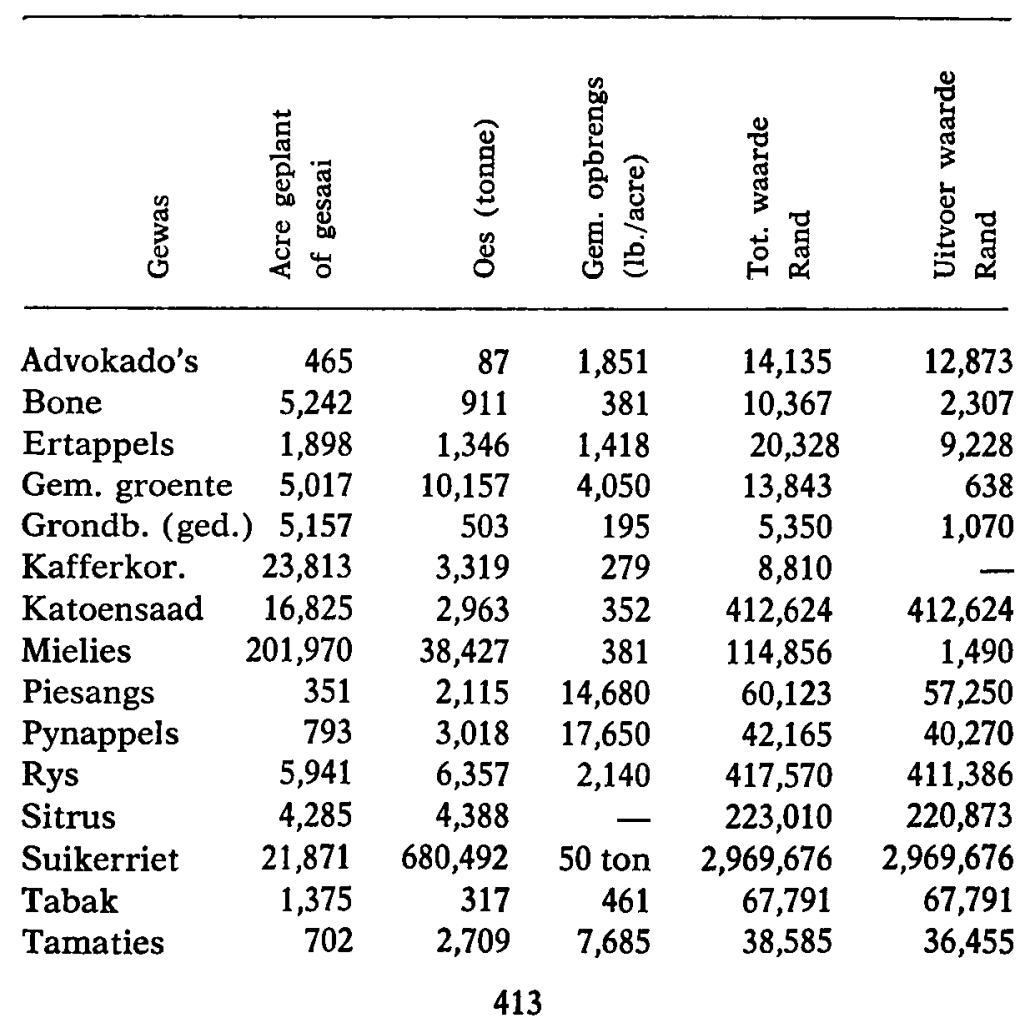


Van die totale waarde van landbouprodukte geproduseer nl. $R 4,424,723$ het die uitvoersyfer $R 4,246,361$ beloop, sodat die plaaslike verbruik R178,362 bedra.

'n Vergelyking van 'n paar gemiddelde opbrengssyfers toon die volgende:

Ertappels ( $37 \frac{1}{2}$ lb. sakkies):

Swaziland (1961-62) ............................... 80 sakkies/morg

R.S.A. (1956-57) ....................................... 262 sakkies/morg

Witbank (Hoëveldstreek 1956—57) ...... 500 sakkies/morg

Mielies (200 lb. sakke):

Swaziland (1961-62) .................................. 4 sak/morg

Bethal (1922-51) ….................................... $10.6 \mathrm{sak} / \mathrm{morg}$

Wolmaransstad (1922-51) ........................... $4.4 \mathrm{sak} / \mathrm{morg}$

Katoen is die belangrikste droëlandgewas en van besondere belang in die ekonomie van Swaziland. Met die nuwe peskontrole word steeds meer katoen onder besproeiing aangeplant.

Die mielieoes van 1961 -62 was weens ongunstige weerstoestande byna 'n mislukking en 170,000 sak moes uit die R.S.A. ingevoer word.

Kafferkoring word in hoofsaak vir bier geproduseer en 27,419 sak moes nog ingevoer word.

Die tabakproduksie was $41 \%$ hoër as die vorige jaar, maar 'n opbrengs van $461 \mathrm{lb}$. per acre vergelyk maar swak met dié van 'n Suid-Rhodesiese boer van $1500 \mathrm{lb}$. per acre.

Die besproeiingsboerdery toon groot vooruitgang. Die totale besproeibare gebied in Swaziland is ongeveer 50,700 acre, waarvan die Malkerns-Mahlanya-gebied ongeveer 10,000 acre onder besproeiing het.

Die volgende punte toon hierdie vooruitgang: i) Die ooreenkoms tussen die R.S.A. en Swaziland waardeur Swaziland

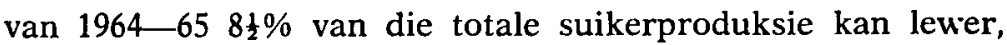
het die bedryf gestimuleer om die vasgepende 80,000 ton suiker na 90,000 ton suiker per jaar op te stoot. In 1962 was dic produksie 76,889 ton suiker waarvan 6,900 ton $(11 \%)$ plaaslik verbruik is.

ii) Sitrusaanplanting het gestyg tot 410,000 bome. Die vernaamste produksiegebiede is Malkerns, Ngonini, Nsoko as- 
ook die Usutu- en Komatibekkens. Lemoene vorm $59.4 \%$ en pomelo's $33.9 \%$ van die aanplantings.

iii) Rysproduksie het gestyg van 4,600 ton tot 6,360 ton met 'n bykomende 1,100 acre aangeplant.

iv) Die pynappels, tamaties en ander vrugte en groente toon ook toenames weens verhoogde produksie.

\section{B. Bosbuu:}

In 1962 was daar in Swaziland en byna heeltemal in die hoëveldstreek 'n totaal van 222,300 acre woude en aangeplante plantasies. Hierdie aanplantings kan volgens boomtipe soos volg verdeel word.

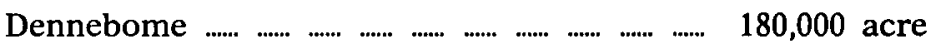

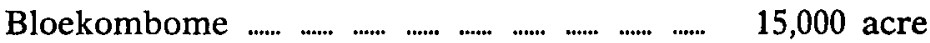

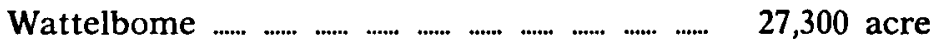

Gedurende die jaar is 3,268 acre denne gekap, wat 7,353 kub. vt. hout gelewer het.

Weens wêreld-oorproduksie word die produksie van wattelbas beperk.

C. Veeteelt:

Die veeteeltsensus van 1962 het die volgende syfers getoon.

TABEL 11.

\begin{tabular}{|c|c|}
\hline Diertipe & Totaal \\
\hline 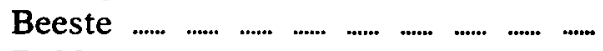 & 543,393 \\
\hline Bokke & 229,049 \\
\hline Skape & 42,775 \\
\hline 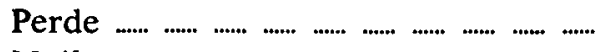 & 2,464 \\
\hline 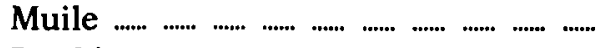 & 788 \\
\hline$\ldots$ & 16,162 \\
\hline 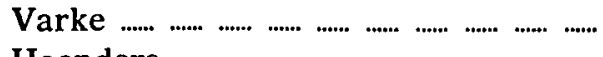 & 96 \\
\hline $\begin{array}{l}\text { S } \quad \ldots \ldots \\
\end{array}$ & \\
\hline
\end{tabular}

Daar is gedurende die jaar 18,267 beeste per veiling verkoop en 43,867 beeste geslag, wat respektiewelik $3.36 \%$ en $\mathbf{8 . 0 7 \%}$ van die totale beesgetalle uitmaak. 
Die "Swaziland Creamery" het in 1962 'n totaal van 373,883 lb. bottervet ontvang, waarvan $86,094 \mathrm{lb}$. of $23 \%$ na die R.S.A. uitgevoer is. Die bottervetproduksie was 459,221 lb., waarvan 239,300 lb. na die R.S.A. uitgevoer is.

Daar is verder ook 21,213 beeste na die R.S.A. uitgevoer volgens kwotas deur die Vleisraad toegestaan. Die beeste is bemark in Johannesburg en Durban.

'n Historiese verskynsel wat vandag nog in Swaziland gevind word, is dat daar in 1962135,178 trekskape van die R.S.A. gedurende die herfs binne gekom het en op 400,000 acre weiding gehou is. Daar het 144,849 trekskape Swaziland verlaat! Skynbaar dus goeie weiding en 'n vrugbare skaapstreek.

Die verslag van die "Commission of Inquiry into the Cattle Industry of Swaziland" wat in November 1962 gepubliseer is, maak ' $n$ hele aantal aanbevelings oor die bemarking en produksiebeleid en het o.a. die oprigting van 'n vleisinmaakfabriek vir Swaziland bepleit.

'n Interessante prosedure wat gevolg word om die oormaat beeste wat deur die Swazi's aangehou word te verminder, is die veevetmaakgebiede („Cattle holding grounds") nl. Impala Ranch 25,000 acre, Ehlane 25,000 acre en Gollel 33,000 acre.

Slegs eersgenoemde gebied word tans gebruik en word heelwat probleme met die eienaars van die beeste ondervind.

Verder is deur die Lifa-fonds en die rasverbeteringskema geprobeer om oorbeweiding en erosie te bekamp, maar die vermindering van die vee-getalle deur hierdie metodes het nog nie die verwagte sukses behaal nie, want die bees bly nog die Swazi se rykdom.

'n Verdere aanbeveling van die kommissie is dat die beesboere bykomende voeding moet voorsien in die moeilike maande, waardeur produksie, re-produksie en verkoopswaarde hoër sal wees en die drakrag per grootvee-eenheid nader aan die ware potensiaal van die gebied sal kom.

Dit moet weer eens beklemtoon word dat landboukundige en veeteeltbeheer, voorligting, opvoeding en navorsing aktief aangepak word deur die amptenare, en 'n mens word beïndruk deur die toegewydheid en entoesiasme waarmee hulle hul taak verrig, nieteenstaande herhaalde teleurstellings wat deur gebrek aan geldelike steun, gebrek aan opgeleide personeel en 
die onontwikkelde bevolking meegebring word.

Wetgewing en regulasies het baie bygedra tot die beheer en herstel van bv. gronde, waar lande alleen geploeg kan word indien kontoerverbouing met grasstroke tussenin beplan word en beeste elke week gedip moet word, behalwe in die winter wanneer hierdie periode tot twee weke verleng word.

3. Bemarking en verwerking van die landbou-, bosbou- en veeteeltprodukte.

a) Die uitvoer van plaas- en bosbouprodukte het in 1962 die eerste keer $R 10,000,000$ oorskry uit 'n totale uitvoer van net meer as R15,000,000. In 1955 het die landbouuitvoerprodukte $\mathrm{R} 2,000,000$ uit 'n uitvoer van $\mathrm{R} 6,600,000$ bedra. Boerderyprodukte vorm dus nou $66 \%$ van die uitvoer, waar dit in 1955 slegs $30 \%$ was. Hiervoor is veral die suiker, hout, sitrus en inmaaknywerheid verantwoordelik.

Tabel 12 toon die afsonderlike produkte wat vir hierdie uitvoersyfer in 1962 verantwoordelik was:

TABEL 12.

Uitvoerprodukte in 1962 ( $\mathrm{R}$ )

Produk

Waarde (R)

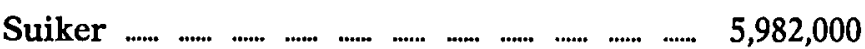

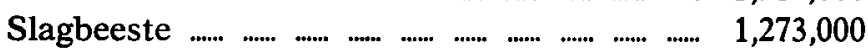

Rys ..................................................................... $\quad 610,000$

Hout ................................................................ $\quad \begin{array}{llll} & 529,000\end{array}$

Katoensaad ….................................................... 413,000

Houtprodukte ...................................................... $\quad 308,000$

Pynappels, ingemaak ........................................ 215,000

Sitrusvrugte, vars ............................................ 207,000

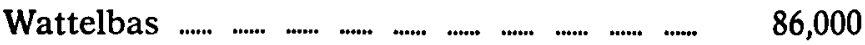

Sitrusvrugte, ingemaak ..................................... $\quad 72,000$

Huide en velle ................................................. $\quad 70,000$

Tabak .......................................................... $\quad 68,000$

Botter ...............................................................

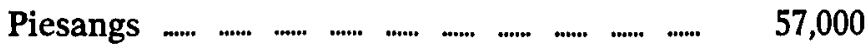


Die invoer van produkte en goedere van landboukundige aard word in 1962 soos volg geskat.

\begin{tabular}{|c|c|}
\hline Item & Naarde (R) \\
\hline Mielies en mielieprodukte $\ldots \ldots \ldots \ldots \ldots \ldots$ & $\ldots . . . .700,000$ \\
\hline Kunsmis & $\ldots \ldots .620,000$ \\
\hline Tabak en sigarette & $\ldots . . .300,000$ \\
\hline Landbou-implemente $\ldots \ldots \ldots \ldots$ & ....... 120,000 \\
\hline Kafferkoring $\ldots \ldots \ldots \ldots$ & ....... $\quad 110,000$ \\
\hline 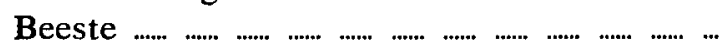 & ...... 106,000 \\
\hline 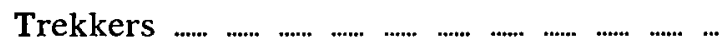 & ...... $\quad 90,000$ \\
\hline 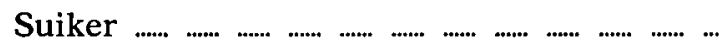 & 85,000 \\
\hline
\end{tabular}

Die veruerking van landbouprodukte vorm natuurlik die belangrikste nywerhede van die gebied, nl. suiker, rys en mieliemeulens, 'n inmaakfabriek vir vrugte en groente; saag., papierpap- en saamgeperste hout-meulens; 'n romery en botterfabriek asook 'n spin- en weefonderneming vir bokhaar en wol.

b) Koöperatiewe verenigings bestaan vir tabak te Goedgegun en rys onder die beheer van die "Swaziland Milling Co. Ltd." Sitrus word bemark deur die "Swaziland Citrus Cooperative Co. Ltd." wat met die Sitrusraad van die R.S.A. geaffilieer is en wat die verkoop van die oes reël.

4. Mynbou is reeds bespreek onder die ekonomiese geologie.

\section{Opwekking van Hidro-elektriese krag.}

Die bestaande kragsentrales in Swaziland is die hidroelektriese skema naby Manzini en 'n dieselopwekker van 550 kw. te Mbabane. Die nywerhede maak gebruik van stoomkragopu'ekking, nl. die saag- en houtmeulens asook die suikermeulens wat hulle eie afvalmateriaal gebruik om krag op te wek. Havelockmyn gebruik steenkool (wat per lugspoor van Barberton vervoer word) om stoomkrag op te wek.

Die stigting van die "Swaziland Electricity Board" in 1962 met die primêre doel om die grootskaalse opwekking en voorsiening van krag in Swaziland te verseker, het 'n aanvangskema van voorsiening gebaseer op 'n hidro-elektriese skema te Edwaleni, vier myl oos van die samevloei van die Klein en 
Groot Usuturiviere, tot gevolg gehad. Hierdie skema sal Manzini, Mbabane, Malkerns, Mhlambanyati en Ingwenya voorsien, terwyl die uitbreiding na Big Bend reeds ondersoek word.

Aangesien Edwaleni sentraal geleë is, sal geen kraglyn langer as 60 myl hoef te wees om enige deel van Swaziland te voorsien nie.

Geen syfers is op hierdie stadium vir die skema beskikbaar nie, en dit sal interessant wees om die koste van opwekking per elektriese eenheid met die stoomkragsentrales van die R.S.A. te vergelyk.

Die koste van die skema bedra R3.4 miljoen en dit sal begin met twee $2.5 \mathrm{MW}$ turbine-omwisselaars, waarby later nog twee $2.5 \mathrm{MW}$ en twee $5 \mathrm{MW}$ stelle geïnstalleer sal word. Indien die aanvraag dit regverdig kan nog twee $5 \mathrm{MW}$ stelle effens laer af by Magaduzu opgerig word. 'n Totaal van 30 MW kan dus opgewek word.

Voorlopig sal slegs die Klein Usutu opgedam word deur 'n studam en word geen groot damme vereis nie.

Die voorsiening van voldoende hidro-elektriese krag sal aan die nywerhede en toekomstige nywerheidsontwikkeling die lang verwagte stimulus $k a n$ gee om die groot potensiaal te ontwikkel, al bly daar dan nog heelwat probleme oor.

\section{Verkeer en verbindings:}

Die invloed van die topografie van Swaziland op die gebied se ontwikkeling a.g.v. die stremming van die ontwikkeling van verkeersfasiliteite is reeds bespreek.

'n Toer deur Swaziland bring hierdie aktuele probleem nog duideliker na vore as die pad van Mbabane - Piggs Peak - Havelock gevolg word en die topografie as 'n verkeershindernis ervaar word.

a) Paaie: Die algemene toestand van die paaie in Swaziland moet beskryf word as goed, angesien die gruispaaie feitlik deurgaans as redelik tot goed bestempel kan word. Die toestand van hierdie paaie gedurende reëntye sal egter verander na suak tot onbegaanbaar. 'n Hele aantal groot brûe voorsien egter permanente oorgang oor al die vernaamste riviere.

Die teerpad van Oshoek-Mbabane-Manzini-Mpaha sou 
vroeg in 1964 voltooi wees en met die voltooiing van die gruispad van Mpaka na Nomahasha sal dit die hoofroete na Mosam. biek vorm. Dit word in die vooruitsig gestel om hierdie deel ook te teer sodra fondse daarvoor beskikbaar is.

'n Verdere deel teerpad strek van Mahlanya na die UsutuPapierpapmeul by Bunya om die vervoer van die papierpap te bespoedig.

Die beplande netwerk van paaie word dan ook as noodsaaklik geag indien dit die nuwe spoorlyn wil aanvul en bedien.

Aangesien die spoorweg nog nie voltooi is nie, word alle vervoer per pad gedoen en word die grootste deel van die passasiers en vrag deur die S.A.S. en H. padmotorvervoerdiens vervoer. Daar is gereelde dienste tussen die vernaamste nedersettings en hulle word ook verbind met die naaste spoorwegstasies in die R.S.A. by Gollel, Piet Retief, Breyten en Komatipoort. Die Camimhos de Ferro de Mocambique verbind ook Stegi met 'n busdiens na Goba, die spoorweg-eindpunt in Mosambiek.

Daar is verder nog 53 passasiersbusse en 91 vrag-voertuie gelisensieer in Swaziland.

b) Spoorweg:

Teen ' $\mathrm{n}$ veruagte koste van $\mathrm{R} 18$ miljoen word 'n spoorlyn van die Mosambiekgrens by Goba oor 'n afstand van 137 myl na Bomvu Ridge gebou om die ystererts te vervoer, om daarmee eerstens die kontrak met Japan vir die lewering van 1.2 tot 1.4 miljoen ton erts per jaar vir 10 jaar na te kom. 'n Kontrak dus vir ongeveer R82 miljoen. Die Portugese het reeds die drie myl spoorweg van Goba na die grens voltooi.

Hierdie spoorweg wat primêr vir die vervoer van ystererts gebou is, sal seker later ook die papierpap van die Usutu-meul, die sitrus en ingemaakte produkte van Malkerns en die steenkool van Mpaka vervoer na Lourenco Marques. Die vraag is egter of dit ook in 'n eenrigting wes-oos vervoersisteem gaan ontwikkel sonder voldoende oos-wes vrag.

Sidvokodvo word die rangeerwerf en spoorwegdorp van hierdie spoorweg.

Dit word verwag dat die spoorweg teen die einde van 1964 voltooi sal wees en 'n aanvang maak met die vervoer van ystererts na Lourenco Marques. 
Die bou van hierdie spoorweg kan beskou word as die grootste enkele deurbraak van die Swazilandse vervoerstelsel, en dit word tot 'n groot mate deur kapitaal uit die R.S.A. gefinansier.

Die vraag bly egter bestaan of 'n verdere aansluiting oos en suidwaarts met die R.S.A. nie vir Swaziland verdere voordele inhou nie, gesien die tipe produk en die mark wat vir hierdie produkte in die R.S.A. bestaan.

c) Lughawes:

Matsapa-lughawe naby Manzini is die enigste toegeruste lughawe in Swaziland wat groter vliegtuie kan hanteer. Die hoofaanloopbaan van 5,200 voet kan die Dakota-tipe hanteer en sodra die aanloopbaan geteer is, sal dit ook geskik wees vir Skymasters. Geskeduleerde vlugte na Johannesburg en Durban bestaan reeds.

Landingstroke vir kleiner vliegtuie bestaan by die meeste nedersettings ( 7 in getal), terwyl die gebruik van die gholfbane van Mbabane en Manzini dien as onoffisiële landingstroke.

d) Verbindings:

Pos word deur die S.A.S. en H. Padmotordiens vervoer binne en buite Swaziland. Daar is 9 kontrolerende met ' $n$ aantal posagentskappe. Die telekommunikasiestelsel tussen Johannesburg en Mbabane is uitgebrei. Outomatiese telefoonsentrales bestaan in Manzini en Mbabane. ' $n$ Semi-outomatiese druktelegraaf-diens is in Mbabane ingestel.

\section{Nywerhede en Nywerheidsontwikkeling:}

Die nywerhede in Swaziland is hoofsaaklik betrokke by die verwerking van die boerdery- en bosbouprodukte soos reeds in Tabel 12 getoon.

Die Usutu-papiermeul het in 1962 sy eerste volle jaar se produksie voltooi en het 34,351 ton ongebleikte sulfaatpap gelewer.

Die saagmeul en geperste houtfabriek van „Peak Timbers", by Piggs Peak, lewer 'n belangrike bydrae, terwyl die naby geleë „Swaziland Plantations" houtkratte en kissies vervaardig.

Die waarde van di bosbouprodukte word in die volgende syfers (1962) weerspieël: 


\begin{tabular}{lcr} 
Tipe produk & Hoeveelheid & Waarde (R) \\
\hline Geskaafde en gesaagde hout & $1,472,000$ kub. vt. & 503,000 \\
Onbewerkte en gelaagde & $2,427,000$ vk. vt. & 190,000 \\
$\quad$ geperste hout & 2,457 ton & 86,450 \\
Droë wattelbas & & 193,700 \\
Ander houtprodukte & & 974,050 \\
Totaal & &
\end{tabular}

Die twee suikermeulens (Big Bend en Mhlume) het beide suikerkwotas van 40,000 ton gehad, wat volgens die jongste ooreenkoms aansienlik verhoog is.

Die „Swaziland Milling Company" hanteer nou behalwe graan ook rys en het 'n rysdroog-aanleg gebou by Manzini.

„Swaziland Canners" by Malkerns verpak veral lemoene, vrugte, vrugtesappe en tamatiepulp en dit word ingemaak vir uitvoer.

In 1962 het „Swaziland Creamery” te Manzini 459,221 lb. botter geproduseer. Die bottervet word hoofsaaklik deur Ban. toeromerye voorsien.

Die ander bedrywighede in die gebied vorm in hoofsaak plaaslike dienste in die verskillende dele van Swaziland, bv. die mineraalwaterfabriek, twee bandeversoolwerke, die drukkery te Mbabane en die beenmeelfabriek by Hluti

Die Swazi's self lewer heelwat handewerk en aandenkings vir toeriste, wat veral te Mbabane, Manzini en Goedgegun te koop aangebied word.

Die uitbreiding van die ligte of sekondêre nywerheidslewe van Swaziland kan binne die volgende paar verwag word, aangesien die spoorweg en die daarmee gepaardgaande nuwe inkomste vir die land al die verskillende sektore van bedryuigheid sal stimuleer.

\section{Die toerisme:}

'n Aspek van Swaziland wat selde genoeg beklemtoon word maar deur almal wat die land besoek, onderskryf word, is dat hier een van die mooiste gebiede in Suidelike Afrika is; van die indrukwekkende bergland van Piggs Peak en Havelock 
tot in Mbabane, deur die Komati Vallei waar die Komati tussen die volsteenblokke deur dreun na die golwende groen landskap van Malkerns en Manzini sowel as die groot Usutu-woud (die tweede grootste deur mense aangeplante woud in die wêreld), die tipiese vaal bos en doringboomveld van die laeveld, die myle en myle groen suikerriet-lande en die indrukwekkende westelike eskarpement van die Lebombo. Geen wonder dat daar gesê is: „If you have travelled Swaziland, you have sampled Africa with the exception of its deserts. For in this pocket handkerchief of a country there is almost every example of African lanscape".

Met die verbetering van die oos-wes padroete na Mosambiek behoort dit 'n populêre roete na Lourenco Marques vir die inwoners van die R.S.A. te word.

Daar is warmbronne by Ezulwini en swawelbronne by Sipofaneni. Die hengelwaters is uitstekend.

Die panorama wat die Barberton-Havelockroete bied, die

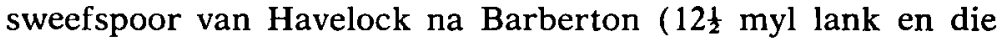
langste in die wêreld) is ' $n$ besondere aantreklikheid.

Die „Swaziland Tourist Association" probeer meer toeriste lok, maar stel meer belang in die hotel-toeris as die kampeer-toeris.

Toerisme bly egter 'n belangrike potensiaal wat Swaziland behoort te ontwikkel.

Erkennings: Ek wil graag my dank betuig aan mnr. J. J. Wessels, wat die gedeelte oor die algemene en ekonomiese geologie opgestel het.

Ook aan mnr. G. F. M. Murdoch van die „Department of Land Utilization" van Swaziland vir sy beskikbaarstelling van gegewens en hulpvaardigheid.

Die kaarte is opgestel uit kaarte deur mnr. Murdoch verskaf en sommige bygewerk uit ander bronne.

J. J. Wessels.

W. J. Voordewind.

P.U. vir C.H.O., Potchefstroom.

1) Swaziland. Annual Report of the Department of Land Utilization. Vol. I. For the year ended 31st December 1961 H.C.P. M73, Mbabane. p. 10. 
2) Swaziland. Report for the year 1962. H.M.S.O. London. 1963.

2) Swaziland. Report for the year 1962. H.M.S.O. Londen. 1963.

4) Green, L. P. en Fair, T. J. D.: Development in Africa. Witwatersrand University Press. Johannesburg, 1962.

5) Swaziland: Report for the year 1962. H.M.S.O. Londen. 1963.

\section{BRONNELYS:}

1. Swaziland. Report for the year 1961. London. H.M.S.O. 1962.

2. Swaziland. Report for the year 1962. London. H.M.S.O., 1963.

3. Green, L. P. en Fair, T. J. D.: Development in Africa. Witwatersrand University Press, Johannesburg. 1962.

4. Official Year Book of the Union of South Africa and of Basutoland, Bechuanaland Protectorate and Swaziland. No. $30-1960$. Union of South Africa. The Government Printer, Pretoria.

5. Financial Mail, The Southern Africa. Special Supplement, November 2, 1962.

6. Shell in Industry. Special Swaziland Issue Jan./March 1962. No. 40. Cape Town.

7. Annual Report of the Department of Land Utilization. Vol. I. for the year ended 31-12-1961. HCP. Mbabane.

8. Annual Report of the Department of Land Utilization. Vol. I. For the year ended 31-12-1962. HCP. Mbabane.

9. Report of the Commission of Enquiry into the Cattle Industry of Swaziland. Nov. 1962. Manzini.

10. Hurter, D. R.: Geology of Swaziland. 1961.

11. S.G.S.M.D.: The Mineral Resources of Swaziland. Bulletin No. 2.

12. S.G.S.M.D.: Annual Reports of the Geological Survey and Mines Department. 1951-1961.

13. S.G.S.M.D.: Special Report No. 3. The Bomvu Ridge Haematite Deposits. 